\title{
MENINGKATKAN KEMAMPUAN KONEKSI MATEMATIS SISWA TUNANETRA DENGAN ALAT PERAGA MANIPULATIF
}

\author{
Deky Yudha Saksono \\ Universitas Muhammadiyah Pekajangan Pekalongan \\ dekyyudha21@gmail.com
}

Received : $28 / 10 / 2019$

Accepted : 29/01/2020

Published : 31/01/2020

\begin{abstract}
The ability of mathematical connections possessed by blind students is said by some experts to be not significantly different by normal students making the writer ask "why are the mathematical abilities of blind students in Indonesia not as good as normal students in general?". After the author learned the condition occurred due to the lack of facilities obtained by blind students. Therefore, the authors are interested in seeing further differences that occur between blind students and normal students, if the blind student is given additional treatment, namely learning with the help of deceptive teaching aids. The abilities that researchers see are more specific to their mathematical connection abilities. This is because the ability of mathematical connections is closely related to the ability of understanding. So it is expected that with the improvement of mathematical connection ability will also improve students' mathematical understanding abilities.
\end{abstract}

Keywords: Blind, Mathematical, Manipulative Props

\section{Abstrak}

Kemampuan koneksi matematis yang dimiliki oleh siswa tunanetra dikatakan oleh beberapa ahli tidak berbeda secara signifikan oleh siswa normal memmunculkan pertanyaan "mengapa kemampuan matematis siswa tunanetra di Indonesia tidak sebaik siswa normal pada umumnya?". Setalah dipelajari kondisi tersebut terjadi karena sedikitnya fasilitas yang didapatkan oleh siswa tunanetra. Oleh karena itu, penelitian ini bertujuan untuk melihat perbedaan lebih lanjut yang terjadi antara siswa tunanetra dan siswa normal, apabila siswa tunanetra diberi perlakuan tambahan yaitu pembelajaran dengan bebantuan alat peraga menipulatif. Kemampuan yang dilihat lebih spesifik pada kemampuan koneksi matematisnya. Hal ini dikarenakan kemampuan koneksi matemtis erat kaitanya dengan kemampuan pemahaman. Sehingga diharapkan dengan membaiknya kemampuan koneksi matematis akan membaik pula kemampuan pemahaman matematis siswa.

Kata Kunci: Tunanetra, Matematis, Koneksi Matematis, Alat Peraga Manipulatif

\section{Pendahuluan}

Berdasarkan UU No. 20 Tahun 2003 tentang Sistem Pendidikan Nasional pada pasal 5: ayat dipaparkan (1) : setiap warga negara mempunyai hak yang sama untuk memperoleh pendidikan yang bermutu, dan di ayat (2) : warga negara yang mempunyai kelainan fisik, emosional, mental, intelektual, dan atau sosial berhak memperoleh pendidkan khusus. Berdasarkan pendapat beberapa ahli (Heyes (Efendi, 2008: 44), (Agrawal, 2004 dalam Tanti) dan (Sumantri, 2006: 71-73)), kemampuan kognitif anak tunanetra sama dengan anak normal. Maka dalam hal ini dapat dikatakan bahwa jika anak tunanetra mendapatkan perlakuan sesuai dengan kekurangan dia dapat mengembangkan kemampuan kognitifnya dg baik. 
Sekolah Luar Biasa (SLB) merupakan suatu pendidikan formal yang disediakan pemerintah bagi mereka yang memiliki kelainan. Tugas pokok dari SLB adalah membantu siswa mencapai perkembangan yang optimal sesuai dengan tingkat dan jenis keluarbiasaanya. Bagi anak yang memiliki kelainan pada penglihatanya yang dikenal dengan tunanetra mendapat layanan pendidikan formal di sekolah luar biasa bagian A atau dikenal dengan SLB A. Kurikulum yang digunakan bagi SLB A memang tidak berbeda jauh dengan kurikulum sekolah bagi siswa normal pada umumnya. Dari segi mata pelajaran yang harus ditempuh, sampai konten materi dalam setiap mata pelajarannya. Hanya saja dalam materi-materi tertentu standar pencapaiannya tidak setinggi pada siswa normal. Misalnya saja dalam standar kompetensi Aljabar, dalam kompetensi dasarnya siswa tidak dituntut untuk mengetahui notasi-notasi pada himpunan. Mereka hanya dituntut untuk menganali himpunan dan jenis-jenisnya, menyelesaikan operasi dalam himpunan, dan mengunakan diagram venn.

Belum tercapainya dengan baik kemampuan pemahaman matematis bagi siswa normal di Indonesia disampaikan oleh beberapa ahli diantaranya Qohar (2010: 733), Wardani (2004), Herman (2010a), Herman (2010b), dan hasil dari penelitian yang dilakukan oleh The Trends in International Mathematics and Science Study (TIMSS) juga memperlihatkan hal yang serupa. Sedangkan rendahnya kemampuan pemahaman matematis siswa tunanetra disampaikan oleh Tillman (dalam Tarsidi) bahwa anak-anak tunanetra mengalami kesulitan pada item-item seperti pada tes pemahaman. Hal ini didukung juga oleh Hidayat dan Abrodi (2011) bahwa, beberapa guru mengakui kemampuan siswa tunanetra hanya sampai pada kemampuan pemahaman dasar.

Sumarmo (2007) bahwa "untuk mencapai pemahaman yang bermakna siswa harus memiliki kemampuan koneksi matematis yang memadai”. Keterkaitan antara kemampuan pemahaman dan koneksi matematis juga disampaikan dalam NCTM (2000:274) bahwa, Thinking mathematically involves looking for connections, and making connections builds mathematical understanding. Without connections, students must learn and remember too many isolated concepts and skills. With connections, they can build new understandings on previous knowledge

Hal senada juga disampaikan oleh Hirdjan (Puspitasari, N. 2010: 5). "Matematika tidak diajarkan secara terpisah antar topik. Masing-masing topik dapat dilibatkan atau terlibat dengan topik lainnya". Oleh karena itu, pemahaman siswa pada suatu topik akan membantu untuk memahami topik yang lain, tetapi hal ini dapat terjadi jika siswa mampu mengkoneksikan topik-topik tersebut. Dengan koneksi siswa juga mampu membangun pemahaman baru berdasarkan pada pengetahuan sebelumnya. Pentingnya kemampuan 
koneksi di dimiliki oleh siswa juga dianjurkan oleh beberapa negara di Dunia, hal ini diungkapkan oleh Nordheimer bahwa "Educational standards all over the world (for example NSC in South Africa, NTSM in USA, diverse curricula in Germany) recommend that teachers enable pupils to recog-nise and to make connections among mathematical ideas". Maka dapat dikatakan untuk meningkatkan kemampuan pemahaman matematis siswa, siswa harus diajarkan juga bagaimana menghubungkan apa yang telah mereka pelajari atau dengan kata lain kemampuan koneksi matematis bisa meningkatkan kemampuan pemahaman matematis siswa.

Beberapa materi matematika yang dirasa sulit bagi anak tunanetra adalah vektor, matriks, geometri, statistika, dan aljabar (Hidayat \& Abrodi: 2011). Kesulitan materi tersebut karena dibutuhkannya kemampuan visualisasi bagi anak tunanetra dalam mempelajarinya. Oleh karena itu, dibutuhkan suatu media agar siswa mampu memvisualisasikan apa yang mereka pelajari dengan baik, sehingga pengetahuan mereka bukan hanya sekedar pengetahuan yang bersifat verbalistik, yakni pengetahuan yang sebatas kata-kata atau suara tanpa memahami makna atau hakikat benda atau objek yang dikenal atau yang dipelajari.

Keterbatasan yang dimiliki oleh siswa tunanetra, menuntut mereka untuk mengembangakan indra lain selain penglihatan dalam menunjang kegiatan belajar mereka. Indra yang cukup berperan memvasilitasi siswa dalam belajar adalah indra pendengaran dan perabaan. Indra pendengaran menjadi indra utama yang digunakan siswa tunanetra dalam menunjang kegiatan belajar-mengajar, namun indra tersebut yang pengambarannya melalui bunyi dalam hal ini suara belum dapat merepresentasikan apa yang sedang mereka pelajari dengan baik. Bahkan seringkali suara yang berhasil ditangkap terdistorsi dengan suara lain, atau berbeda dengan mental map yang tumbuh dalam diri siswa tunanetra. Oleh karena itu, diperlukan media pendukung lain selain suara.

Indra lain yang cukup efektif mengantikan indra penglihatan adalah indra perabaan. Hallahan dan Kauffman (1991, dalam Tarsidi) berpendapat bahwa "untuk memperkaya kognisi anak tunanetra, mareka harus sering didorong untuk menggunakan indra perabaannya". Peneliti mencoba untuk melihat pengaruh pembelajaran dengan berbantuan alat pegara manipulatif terhadap kemampuan koneksi matematis siswa Sekolah Menengah Pertama Luar Biasa A (siswa tunanetra) dan untuk melihat apakah terdapat perbedaan kemampuan koneksi matematis sisiwa tunanetra dengan sisiwa normal, jika siswa tunanetra diberi fasilitas alat peraga manipulatif dalam pembelajarannya, sedangkan siswa normal belajar secara konvensional dan untuk melihat bagaimana respos siswa tunanetra terhadap pembelajaran dengan berbantuan alat peraga manipulatif. 
Koneksi matematis menurut Ruspiani (2000) adalah kemampuan siswa mengaitkan konsep-konsep matematika baik antar konsep matematika maupun mengaitkan konsep matematika dengan bidang ilmu lainnya (di luar matematika). Pengertian itu juga sejalan dengan definisi kemampuan koneksi matematis menurut NCTM. Menurut NCTM (Anita, 2011) disebutkan bahwa koneksi matematis dibagi menjadi tiga klasifikasi, yaitu (a) koneksi antartopik matematika, (b) koneksi dengan disiplin ilmu lain, dan (c) koneksi dengan masalah-masalah dalam kehidupan sehari-hari.

Alat peraga matematika sebagai suatu alat yang penggunaannya diintegrasikan dengan tujuan dan isi pengajaran yang telah dituangkan dalam Garis Besar Program Pengajaran mata pelajaran matematika dan bertujuan untuk mempertinggi mutu kegiatan belajar mengajar (Darhim, 2002: 5). Ruseffendi (2005) juga menekankan bahwa, alat pegara merupakan alat untuk menerangkan atau mewujudkan konsep metematika di dalam kegiatan mendidik atau mengajar supaya dijadikan mudah untuk dimengerti. Estiningsih (1994) juga memaparkan hal yang sama bahwa alat peraga merupakan media pengajaran yang mengandung atau membawakan ciri-ciri dari konsep yang dipelajari.

Namun Iswadji (Pujiati, 2004: 3) memaparkan pengertian alat peraga dengan lebih rinci, dengan mengatakan bahwa alat peraga matematika adalah seperangkat benda kongkrit yang dirancang, dibuat, dihimpun, atau disusun secara sengaja yang digunakan untuk membantu menanamkan atau mengembangkan konsep-konsep dalam matematika. Dari pendapat-pendapat tersebut dapat disimpulkan bahwa alat peraga adalah alat yang digunakan untuk membantu pengajaran konsep-konsep matematika agar lebih mudah untuk dimengerti siswa.

Schweyer (2000: 4) berpendapat bahwa A mathematical manipulative is defined as any material or object from the real world that children move around to show a mathematics concept. They are concrete, hands-on models that appeal to the senses and can be touched by students. These materials should relate to a student's real world.

Ada beberapa nilai praktis jika pembelajaran mengunakan alat peraga, yaitu: (a) alat peraga dapat mengatasi perbedaan pengalaman siswa; (b) alat peraga dapat membangkitkan semangat belajar yang baru dan membangkitkan motivasi serta merangsang kegiatan siswa dalam belajar; (c) alat peraga dapat mempengaruhi abstraksi; dan (d) alat peraga dapat memperkenalkan, memperbaiki, meningkatkan, dan memperjelas pengertian konsep dan fakta.

Ruseffendi (1979:1) memaparkan beberapa keunggulan jika pembelajaran matematika menggunakan alat peraga, yaitu: (a) Proses belajar mengajar termotivasi. Baik siswa maupun guru minatnya akan timbul. Namun, siswa akan lebih senang, terangsang, tertarik, dan karena 
itu akan bersikap positif terhadap pengajaran matematika. (b) Konsep abstrak dalam matematika tersajikan dalam bentuk kongkrit dan kerena itu lebih dapat dipahami dan dimengerti, serta dapat ditanamkan pada tingkat-tingkat yang lebih rendah. (c) Hubungan antara konsep abstrak matematika dengan benda-benda di alam sekitar akan lebih dapat dipahami. (d) Konsep-konsep abstrak yang tersaji dalam bentuk kongkrit yaitu dalam bentuk model matematika yang dapat dipakai sebagai obyek penelitian maupun sebagai alat untuk meneliti ide-ide baru dan relasi baru menjadi bertambah banyak.

Tunanetra berdasarkan konsensus internasional dibagi menjadi dua, yaitu definisi secara legal dan definisi secara edukasional. Definisi secara legal mengacu pada peraturan perundang-undangan. Dimana pendefinisiannya berdasarkan dua aspek yaitu ketajaman penglihatan (visual acuity) dan medan pandangan (visual field). Berdasarkan dua aspek tersebut, siswa yang mengalami kehilangan penglihatan (visual impairment) adalah siswa yang mempunyai ketajaman penglihatan 20/200 atau lebih buruk dari itu setelah dikoreksi dengan menggunakan lensa, dan memiliki medan pandang tidak lebih dari $20^{\circ}$ (Scholl Geraldine, 1986 dalam Alimin). Ketajaman penglihatan 20/200 terjadi bila mana siswa dapat melihat simbol atau huruf pada snellen chart dari jarak 20 kaki yang oleh siswa lain (normal) dapat melihat dari jarak 200 kaki.

Namun, beberapa ahli berpendapat bahwa siswa dikatakan tunanetra apabila ketajaman penglihatannya kurang dari 6/21, yang berarti siswa hanya mampu membaca huruf pada jarak 6 meter yang oleh siswa normal dapat dibaca pada jarak 21 meter. Terdapat perbedaan pengukuran yang siknifikan antara dua pendapat tersebut, namun secara garis besar para ahli mengkategorikan siswa yang ketajaman penglihatannya kurang dari 6/21 sebagai siswa tunanetra. Dalam penelitian ini yang kami rujuk sebagai siswa tunanetra sesuai dengan definisi secara edukasional, yaitu semua siswa yang mmengalami hambatan dalam belajar yang mengakibatkan adanya gangguan dalam penglihatan. Sehingga tidak terjadi perbedaan perlakuan lebih dalam penelitian anatara siswa yang mengalami kebutaan total atau sebagian.

\section{Metode Penelitian}

Metode penelitian yang digunakan adalah metode kuantitatif dengan desain penelitian kelompok kontrol non-ekivalen. Penelitian ini akan melihat peningkatan kemampuan koneksi matematis siswa tunanetra dan membandingkan kemampuan koneksi siswa tunanetra dengan siswa normal yang berada pada sekolah dalam kategori sedang dan rendang. Instrumen yang digunakan dalam penelitian ini berupa instrumen tes dan non tes. Instrumen tes terdiri dari tes yang digunakan untuk mengukur kemampuan koneksi matematis, yang diberikan sebelum pemebelajaran pada siswa tunanetra dan sesudah pembelajaran yang diberikan pada semua 
subyek dalam penelitian. Sedangkan instrumen non tes terdiri dari lembar observasi, wawancara, dan journal yang diperoleh dengan cara deskriptif.

\section{Hasil dan Pembahasan}

Guna memberi gambaran hasil data penelitian berupa skor kemampuan koneksi matematis yang diperolah, berikut akan disajikan data skor siswa melalui statistik deskriptif.

\section{Tabel}

Statistik Deskriptif Kemampuan Koneksi Matematis

\begin{tabular}{|c|l|l|l|l|l|l|}
\hline \multirow{2}{*}{ Kategori } & \multicolumn{2}{|l|}{$\begin{array}{l}\text { Kelas Siswa } \\
\text { Tunanetra }\end{array}$} & \multicolumn{2}{l|}{$\begin{array}{l}\text { Kelas Siswa Normal } \\
\text { Kategori Sedang }\end{array}$} & \multicolumn{2}{l|}{$\begin{array}{l}\text { Kelas Siswa Normal } \\
\text { Kategori Rendah }\end{array}$} \\
\cline { 2 - 7 } & Pretes & Postes & Pretes & Postes & Pretes & Postes \\
\hline $\mathrm{N}$ & 11 & 11 & - & 20 & - & 20 \\
\hline$x_{\min }$ & 0 & 3 & - & 0 & - & 0 \\
\hline$x_{\operatorname{maks}}$ & 10 & 30 & - & 30 & - & 12 \\
\hline $\bar{x}$ & 2,73 & 17,91 & - & 10,75 & - & 3,8 \\
\hline$\%$ & 9,09 & 59,7 & - & 35,8 & - & 12,7 \\
\hline$S$ & 4,67 & 9,64 & - & 7,94 & - & 3,15 \\
\hline $\begin{array}{l}\text { Skor } \\
\text { Ideal }\end{array}$ & \multicolumn{7}{|l}{30} & & \\
\hline
\end{tabular}

Dari tabel diatas dapat diketahui bahwa siswa normal tidak dilakukan pretes. Hal ini dikarenakan, mata sebagai indra penglihatan mempunyai kontribusi $80 \%$ - $85 \%$ bagi seseorang melakukan aktivitas apapun, termasuk dalam belajar. Oleh karena itu, kita mengasumsikan bahwa kemampuan awal mereka tidak sama dan dalam penelitian ini akan melihat apakah pembelajaran dengan alat peraga manipulatif yang diberikan pada siswa tunanetra mampu membuat kemampuan koneksi matematis mereka tidak berbeda secara signifikan dengan siswa normal.

Data rerata skor pretes dan postes kemampuan koneksi matemtis siswa tunanetra adalah 2,72 untuk pretest dan 17,91 untuk postest. Hasil tersebut jelas cukup besar perbedaanya dan memperlihatkan adanya peningkatan yang cukup besar pula pada kemampuan koneksi matematis siswa tunanetra. Peningkatan yang terjadi ini setelah dilakukan perhitungan dengan gain ternormalisasi memberikan rerata $\mathrm{N}$-gain sebesar 0,58. Setelah dilakukan uji-t satu sampel memberikan hasil bahwa, rerata tersebut lebih dari 0,3. Hal ini dapat diartikan bahwa, dengan alat peraga manipulatif mampu neningkatkan kemampuan koneksi matematis siswa tunanetra dalam kategori $\mathrm{N}$-gain sedang.

Peningkatan kemampuan koneksi matematis siswa tunanetra setelah diberikan pembelajaran dengan alat peraga manipulatif senada dengan pendapat Ruseffendi (1979:1) bahwa "hubungan antara konsep abstrak matematika akan lebih dapat dipahami". Selain itu dapat pula kita katakan bahwa dengan adanya alat peraga mampulatif memfasilitasi siswa 
tunanetra untuk belajar secara maksimal, sehingga siswa tunanetra mampu mengoptimalkan kemampuannya, yang membuat mereka memiliki kemampuan yang tidak berbeda secara signifikan dengan siswa normal pada umumnya.

Pembelajaran dengan alat peraga manipulatif adalah suatu pembelajaran yang menyediakan alat dimana pengunanya diintegrasikan dengan tujuan dan isi pengajaran. Dalam penelitian ini alat peraga manipulatif tidak hanya disediakan sebagai sarana untuk memvisualisasikan pengetahuan siswa tunanetra terhadap suatu benda atau obyek yang mereka ketahui secara verbal. Namun juga sebagai sarana untuk mengajarkan suatu konsep baru kepada mereka.

Tahapan-tahapan yang dirancang dalam penelitian ini adalah tahap pemberian pertanyaan kepada siswa yang diharapkan dapat meningkatkan daya ingin tahunya melalui lembar aktivitas siswa, pengumpulan data atau informasi yang berkaitan dengan pertanyaan yang diberikan dalam lembar aktifitas siswa dengan bantuan alat peraga yang diberikan, mempresentasikan hasil temuan, dan terakhir menyimpulkan hasil temuan-temuan tersebut bersama dengan guru. Melalui proses pengumpulan informasi dengan meraba atau mengamati alat peraga menipulatif yang diberikan, membuat pengetahuan siswa secara verbal tervisualisasikan dengan rabaan tangan. Hal ini akan memberikan pengalaman yang lebih kaya kepada siswa tunanetra, sehingga pemahaman mereka mengenai sesuatu yang diperoleh lebih bermakna.

Lembar aktivitas siswa yang disusun sedemikian rupa untuk menunjang pembelajaran dengan alat peraga manipulatif, membarikan arahan kepada siswa untuk menemukan suatu konsep baru dengan cara menghubungkan data atau pengetahuan yang telah mereka dapatkan sebelumnya, dan memberikan latihan kepada siswa untuk belajar mengkoneksikan. Adanya sarana untuk siswa belajar menemukan suatu konsep baru dengan cara menghubungkan atau mengkoneksikan pengetahuan yang telah mereka pelajarai sebelumnya, membuat siswa terbiasa untuk menyelesaikan masalah yang berkaitan dengan kemampauan koneksi matematis. Kondisi itulah yang mengakibatkan kemampuan koneksi matematis siwa tunanetra meningkat cukup baik setelah dilakukan pembelajaran dengan alat peraga manipulatif.

Lembar aktifitas siswa yang diberikan kepada siswa memang menjadi faktor pendukung meningkatnya kemampuan koneksi matematis siswa. Namun dalam implementasinya tidak semudah itu untuk diterapkan. Hal ini dikarenakan siswa tunanetra yang kami teliti tidak terbiasa menggunakan lembar aktifitas siswa atau buku ajar yang menuntut mereka untuk belajar secara mamdiri dengan membaca. Maka diawal-awal penelitian kami, kami mendapat proter yang cukup keras dari siswa, hingga kami harus sedikit merubah lembar aktifitas yang telah kami rancang, namun kami tidak menghilangkanya 
dalam pembelajaran. Karena kami berpendapat, bagaimanapun juga siswa tunanetra harus diajarkan untuk belajar mandiri dengan membaca. Temuan lain yang kami dapatkan selama penelitian berdasarkan lembar observasi siswa, wawancara, dan jurnal adalah tidak semua siswa tunanetra mampu sampai pada tahap kemampuan koneksi matematis. Terlebih pada bagian mengkoneksikan keterkaitan antara dua konsep, hanya beberapa siswa yang mampu memahami dengan baik. Setelah kami amati lebih mendalam, hal ini dikarenakan kemampuan pemahaman matematis mereka yang masih rendah. Data yang kami peroleh dari 11 siswa dalam kelas tunanetra terdapat 3 siswa yang kemampuan pemahaman matematisnya masih sangat rendah.

Berdasarkan wawancara dengan guru kelas, ketiga siswa tersebut juga mengalami hambatan dalam belajar, baik itu belajar matematika ataupun belajar matapelajaran yang lain. Selama penelitian bimbingan individu sebagai layanan utama dalam pembelajaran juga sudah dilakukan, namun dari hasil postes tetap menunjukkan kemampuan koneksi mereka tidak meningkat dengan baik. Sampai penelitian kami selesai, kami beleum mendapatkan formula yang tepat untuk mengatasi hal tersebut.

Hal lain yang cukup mengejutkan dalam penelitian ini adalah hasil dari post test kemampuan koneksi matematis pada siswa tunanetra dan siswa normal pada ketegori sekolah sedang dan rendah. Berdasarkan data, diperoleh skor rerata postes siswa tuanatra adalah 17,91, sedangkan untuk siswa normal dengan kategori sekolah sedang adalah 10,75 dan untuk siswa normal dengan kategori sekolah rendah adalah 3,8. Hasil ini cukup mengejutkan karena siswa tunanetra memperolah rerata yang paling tinggi. Setelah dilakukan uji Independent Sampel Test dan uji Menn-Whitny memberikan hasil bahwa terdapat perbedaan yang signifikan antara rerata postes kemampuan koneksi siswa tunanetra dengan siswa normal dari kategori sekolah sedang, maupun dengan ketegori sekolah rendah. Hal ini berarti, pembelajaran dengan berbantuan alat peraga menipulatif dapat mengatasi hambatan siswa dalam penglihatan sehingga mereka mampu meningkatkan kemampuan metematis mereka terlebih kemampuan koneksi matematisnya..

Perbedaan yang terjadi pada kemampuan koneksi ini memang cukup mengejutkan, karena dengan berkurangnya 80-85\% kemampuan siswa tunanetra untuk mengeksplorasi lingkungan, mereka mampu melebihi siswa normal pada kategori sekolah sedang dan rendah dalam kemampuan koneksi matematis. Perbedaan yang signifikan ini terjadi jelas tidak semata-mata karena pembelajaran dengan berbantuan alat peraga, melainkan juga dari kemampuan yang dimiliki oleh siswa tunanetra itu sendiri. Sepertihalnya ungkapan Tarsidi bahwa "seorang anak tunanetra mungkin miskin dengan konsep-konsep tertentu, tetapi kaya 
dengan konsep-konsep lain". Konsep lain disini yang belum dapat diketahui oleh peneliti dengan keterbatasanya.

Perbedaan yang cukup mencolok dari kemampuan siswa tunanetra dan normal dalam kemampuan koneksi matematis adalah kemampuan mereka dalam mengerjakan soal post test. Perbedaan yang mencolok ini ditunjukkan dari banyaknya siswa normal yang mampu menjawab butir soal nomor 3 dengan baik, namun bagi siswa tunanetra butir soal tersebut tergolong sulit. Namun bagi siswa normal, butir soal nomor 1, tergolong sulit bagi mereka untuk dikerjakan. Ada sebuah pertanyaan yang muncul dalam diri peneliti, mengapa perbedaan tingkat pencapaiaan itu terjadi? Ternyata yang membedakan adalah cara pikir dan adanya vasilitas penglihatan yang dimiiliki oleh siswa normal. Pada butir soal 1 dengan soal dan analisisnya sebagai berikut:

Soal:

Luas sebuah belahketupat adalah $36 \mathrm{~cm}^{2}$. Jika perbandingan panjang diagonal-diagonalnya adalah 1: 2. Berapakah panjang diagonal-diagonalnya?

Hanya ada dua siswa dari sekolah kategori sedang dan rendah yang mampu menjawab soal diatas. Berdasarkan pengamatan, hal yang menghambat mereka untuk menyelesaikun butir soal tersebut adalah ketidak fahaman mereka mengenai perbandingan diagonal yang disajikan. Jikapun mereka faham, mereka tidak dapat memahami prosedur penyelesaanya. Namun bagi siswa normal yang faham akan konsep perbandingan yang disajikan, mereka dapat mengerjakan dengan baik. Berikut dilampirkan jawaban siswa normal yang mampu menyelesaikan masalah diatas.

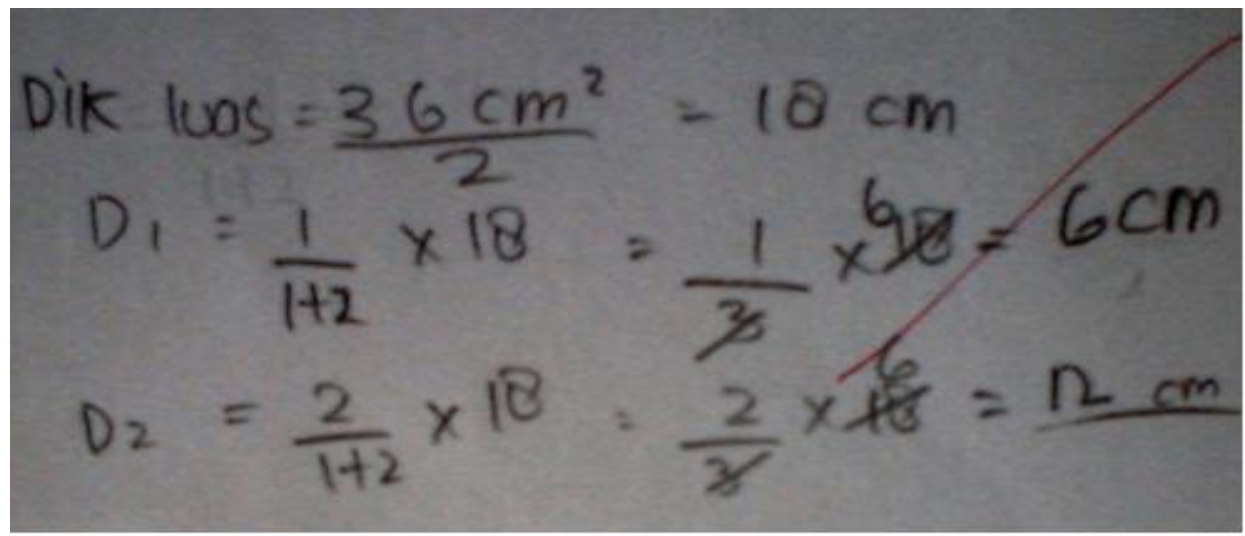

Gambar 4.1 Hasil Kerja Siswa Normal

Dari jawaban siswa pada Gambar 4.1 sangat terlihat kefahaman siswa mengenai perbandingan. Sehingga siswa mampu menyelesaikanya sesuai dengan prosedur. 
Adapun jawaban dari siswa tunanetra setelah disalin dalam huruf latin adalah sebagi berikut:

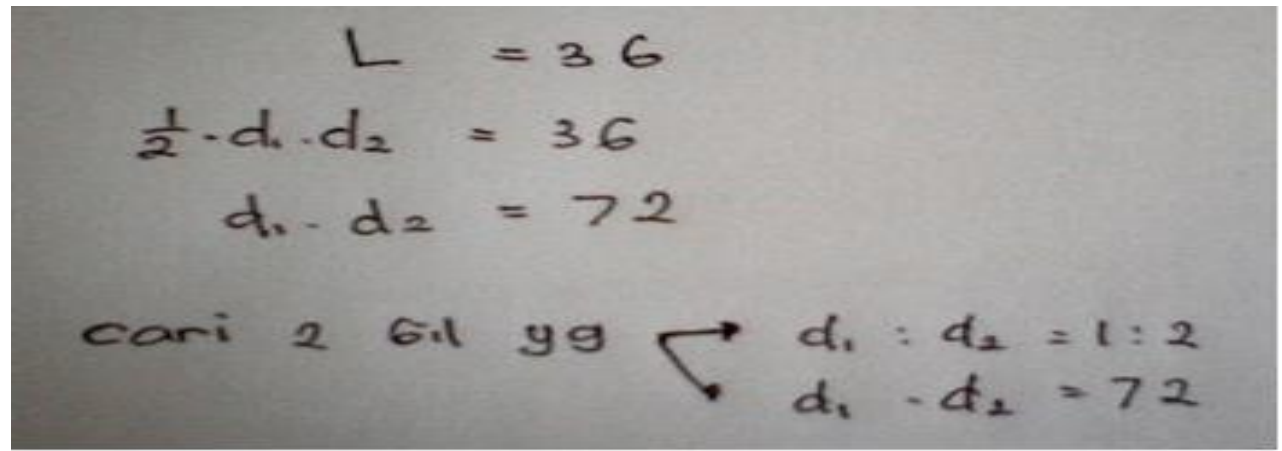

Gambar 4.2. Hasil Kerja Siswa Tunanetra

Dari jawaban siswa tersebut, siswa tunanetra mengambil proses berfikir yang terlihat semuanya dibayangkan, bukan dari hasil prosedural seperti siswa normal. Siswa tunanetra memilih cara bagaimana mereka bisa menyederhanakan masalah sehingga logika mereka bias berjalan lebih mudah untuk menyelesaikannya. Berbeda dari jawaban siswa normal yang mampu menyelesaikan masalah diatas. Mereka terbiasa mengerjakan dengan cara yang runtut berdasarkan prosedur yang mereka ketahui mengenai penyelesaian masalah perbandingan. Kondisi ini juga memberikan gambaran bahwa siswa normal baru mampu menyelesaikan soal secara prosedural, sehingga jika prosedur dalam penyelesaian soal tersebut tidak mereka ketahui maka mereka tidak dapat menyelesaikan soal yang diberikan.

Pada butir soal ke-3 dengan indikator mencari hubungan berbagai konsep, memahami hubungan antar topik matematika, dan mencari hubungan suatu prosedur dengan prosedur lain, terdapat kesulitan bagi siswa tunanetra untuk menyelesaikanya. Namun bagi siswa normal, soal tersebut dapat dikerjakan dengan baik. Berikut soal dan analisisnya:

Soal: Berikan contoh ukuran persegi dan persegi panjang yang memiliki luas yang sama namun kelilingnya berbeda!

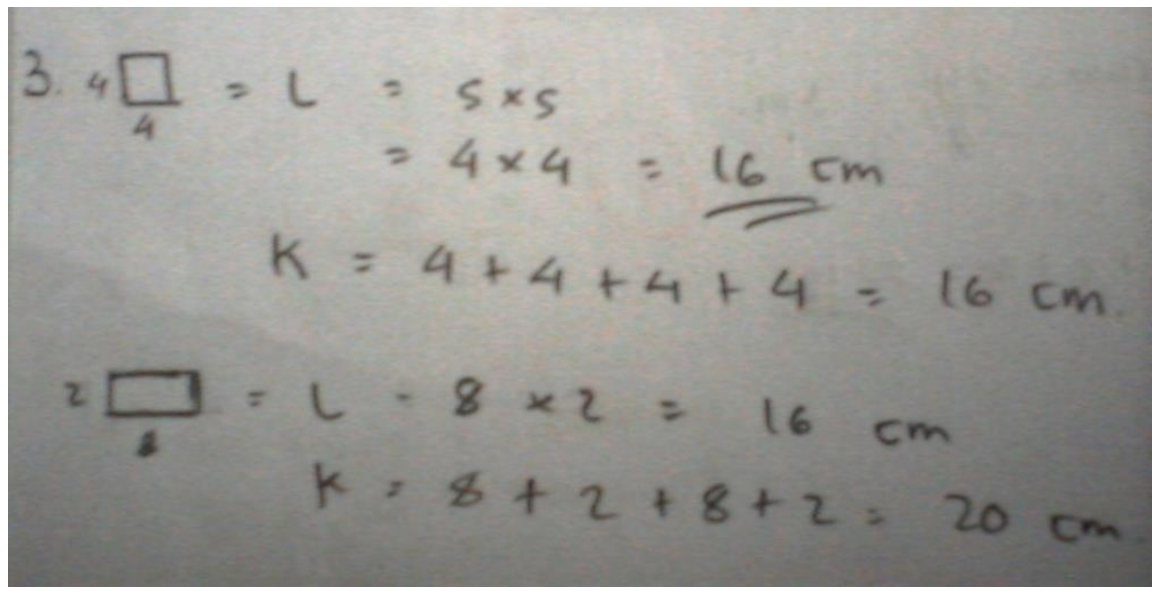

Gambar 4.3 Hasil Kerja Siswa Normal 
Terjadinya perbedaan cara berfikir dan vasilitas mata yang membuat pencapaian soal tersebut relatif kecil bagi siswa tunanetra. Dengan bantuan gambar persegi dan persegipanjang seperti pada Gambar 4.3, siswa normal mampu memetakan pikiranya dengan baik. Namun siswa tunanetra dengan keterbatasan penglihatan, menyelesaikan masalah tersebut dengan dibayangkan. Jika siswa belum faham arah penyelesaiannya, mereka tidak mampu memetakan pikirannya untuk menyelesaikan masalah tersebut. Ketercapaian siswa normal dalam masalah ini didukung oleh pendapat Coxford (1995 dalam House, 1995) bahawa penghubung-penghubung matematis seperti grafik, gambar membantu siswa untuk melakukan koneksi lebih mudah.

Beberapa siswa yang mampu menyelesaikan masalah tersebut mengungkapkan dalam wawancara hasil pekerjaanya bahwa, untuk menyelesaikan masalah itu siswa mencari bilangan berpangkat, lalu mencari dua biangan lain yang jika dikalikan akan menghasilkan nilai yang sama dengan bilangan berpangkat tersebut. Misalnya mereka memilih bilangan berpangkat 36, lalu mencari dua bilangan lain yang jika dikalikan menghasilkan bilangan 36, namun dari dua bilangan tersebut bukan bilangan yang sama. Kondisi ini menunjukkan adanya koneksi yang baik dalam diri siswa, koneksi antar konsep luas persegi dengan persegi panjang ataupun konsep luas tersebut dengan perkalian bilangan berpangkat.

\section{Kesimpulan}

Kesimpulan pada penelitian sebagai berikut: (1) pembelajaran dengan berbantuan alat peraga menipulatif dapat meningkatkan kemampuan koneksi matematis siswa tunanetra; (2) kemampuan koneksi matematis siswa tunanetra yang yang belajar dengan berbantuan alat peraga manipulatif lebih baik dari kemampuan koneksi matematis siswa normal yang belajar secara konvensional; (5) adanya respon yang baik yang diberiken oleh siswa terkalit pembelajaran dengan alat peraga manipulatif.

\section{Pustaka}

Cox, P. R. \& Dykes, M. K. 2001. "Classroom Adaptations for Students with Visual Impairment”. Teaching Exceptional Children. 33(6). 68-74.

Efendi, M. 2008. Pengantar Psikopedagogik Anak Berkelainan. Jakarta: Bumi Aksara.

Hidayat, W. dan Abdorin, M. 2011. Profil Kemampuan Matematika Anak Berkebutuhan Khusus (Tunanetra) Di Yaketunis Yogyakarta. Artikel. Tersedia http://muhamadabdorin.blogspot.com/2011/11/normal-0-false-false-false-en-us-X-none.html. $\quad[12$ Oktober 2012].

National Council of Teacher of Mathematics. 1989. Curriculum and Evaluation Standards for School Mathematics, Reaston, VA: NCTM. 
Pujiati. 2004. Pengunaan Alat Peraga dalam Pembelajaran Matematika SMP. Yogyakarta: PPPG Matematika.

Puspitasari, N. 2010. Pembelajaran Berbasis Masalah dengan Strategi Kooperatif JIGSAW untuk Meningkatkan Kemampuan Pemahaman dan Koneksi Matematis Siswa Sekolah Menengah Pertama. Tesis. SPS UPI Bandung: tidak diterbitkan.

Qohar, A. 2010. Developing Mathematical Understanding Instruments for Secondary School Students. [Online]. Tersedia: http:// file.upi.edu/.../ Developing_mathematical_understanding_instruments_for_secondary_school_stud ents.pdf. [10 November 2012].

Ruseffendi, E. T. 2005. Dasar-dasar Matematika Modern dan Computer. Bandung: Tarsito.

Ruseffendi. E. T. 2005. Dasar-dasar Penelitian dan Bidang Non Eksakta. Bandung: Tarsito.

Ruspiani. 2000. Kemampuan Siswa dalam Melakukan Koneksi Matematika. Tesis. SPS UPI Bandung: tidak diterbitkan.

Tanti, M. 2011. Teaching Mathematics to Ablind Student -A Case Study-. [Online]. Tersedia: http://freedownloadb.com/pdf/eaching-athematics-to-lind-tudent-ase-tudy5529479.html [3Agustus 2012] 